\title{
Resistance levels of Arabica coffee cultivars to bacterial-halo-blight under field conditions and planting spacings within the rows
}

\author{
Fernando Cesar Carducci $^{1,2}$, Willian Gabriel dos Santos ${ }^{1}$, Carlos Theodoro Motta Pereira ${ }^{1}$, Lucas Mateus \\ Rivero Rodrigues ${ }^{3}$, Luís Otávio Saggion Beriam ${ }^{4}$, Luciana Harumi Shigueoka ${ }^{1}$, Valdir Mariucci Junior ${ }^{1,2}$, Kawana \\ Silva Bortolato ${ }^{1,2}$, Gustavo Hiroshi Sera ${ }^{{ }^{*}}$
}

\author{
${ }^{1}$ Instituto de Desenvolvimento Rural do Paraná - IAPAR-EMATER (IDR-Paraná), Plant Breeding Department, Rodovia \\ Celso Garcia Cid, km 375, Zip Code 86047-902, Londrina-PR, Brazil \\ ${ }^{2}$ Universidade Estadual de Londrina (UEL), Agronomy Department, Rodovia Celso Garcia Cid, km 380, Zip Code 86057- \\ 970, Londrina-PR, Brazil \\ ${ }^{3}$ Instituto Agronômico (IAC) Centro de Café Alcides Carvalho, CP 28, Zip Code 13001-970, Campinas-SP, Brazil \\ ${ }^{4}$ Instituto Biológico, CP 70, Zip Code 13012-970, Campinas-SP, Brazil
}

*Corresponding author: gustavosera@idr.pr.gov.br

\begin{abstract}
Bacterial-halo-blight (BHB) is an important coffee disease caused by the Pseudomonas syringae pv. garcae. To date, there are few studies reporting resistance to $\mathrm{BHB}$ in adult plants of Arabica coffee cultivars under field conditions. The aim of this study was to assess the levels of resistance to BHB in Arabica coffee cultivars under field conditions and different planting spacings within the rows (SWR). The field trial was assessed for BHB severity in natural infection condition by using a grade scale, ranging from 1 to 5 in Londrina (Paraná state, Brazil) in December 2016 (36 months after planting). The experiment was planted at the 2.50m spacing inter-row, using randomized blocks design in a $4 \times 15$ factorial scheme with three replications and five plants per plot. The factors consisted of four SWR $(0.40 \mathrm{~m}, 0.50 \mathrm{~m}, 0.60 \mathrm{~m}$ and $0.70 \mathrm{~m})$ and 15 Arabica coffee cultivars. The resistance levels were based on the mean BHB severity grades, where the cultivars were classified as highly resistant $(H R)$, resistant $(R)$, moderately resistant (MR), slightly resistant (SR) and susceptible (S). Adult plants of IPR 102 and IPR 106 were HR and MR to BHB, respectively, under natural field conditions. IAPAR 59, IPR 103, IPR 104, IPR 107 and IPR 108 showed a lower level of resistance than the cultivars IPR 102 and IPR 106. Some HdT-derived cultivars such as IPR 97, IPR 98, IPR 99 and Tupi IAC 1669-33, besides cultivars IPR 100, IPR 101 and IPR 105, derived from IAC 1110-8 were susceptible. In the two SWR more densely, the BHB severity was higher, and some cultivars behaved as more susceptible in these spacings.
\end{abstract}

Keywords: bacteria, Coffea, IPR, planting densities, Pseudomonas syringae pv. garcae.

Abbreviations: BHB_Bacterial-halo-blight; HdT_Híbrido de Timor; IAPAR-EMATER_IDR-Paraná_Instituto de Desenvolvimento Rural do Paraná - IAPAR-EMATER; SWR_spacing within the rows; HR_highly resistant; R_resistant; MR_moderately resistant; SR_slightly resistant; S_susceptible; IAC_Instituto Agronômico.

Introduction

Bacterial-halo-blight (BHB) is an important coffee disease caused by the Pseudomonas syringae pv. garcae (Amaral et al., 1956), which occurs more frequently in crops of high altitude regions, with mild temperatures, high rainfall, and which are exposed to strong and or constant winds, and occasional frost (Zoccoli et al., 2011). In these more favorable environmental conditions, the BHB causes losses in production in important coffee producing states of Brazil such as Minas Gerais, São Paulo and Paraná (Moraes et al., 1975; Petek et al., 2006; Ito et al., 2008; Zoccoli et al., 2011; Rodrigues et al., 2017). Besides Brazil, this disease has already been found in Kenya (Ramos and Shavdia, 1976; Ithiru et al., 2013), Ethiopia (Korobko and Wondimagegne, 1997), Uganda (Ramos and Shavdia, 1976) and China (Xuehui et al., 2013).

The BHB symptoms occur in leaves, young fruits and branches. Lesions on the leaves are irregular and of a brownish-brown color with yellowish halo around them are more common on the edges of the leaves, where it is easier for bacteria to 
penetrate due to mechanical damages. However, they can extend throughout the leaf surface. In more severe attacks necrosis of branches and young fruits may occur. Young plants are more susceptible and may suffer leaf shedding, die-back of the branches, over sprouting and delayed early development (Amaral et al., 1956).

The main control measures are (a) the use of wind breaks (Patrício et al., 2010); (b) chemical control by using antibiotics, copper-based products and resistance inducer (Patrício et al., 2008); (c) use of resistant cultivars (Ito et al., 2008). The latter is the most appropriate measure, since it is efficient and avoids the use of chemical products in the coffee. Sources of resistance to BHB were identified in Arabica coffees from Ethiopia and in other species, from different geographical origins, such as C. canephora, C. eugenioides, C. stenophylla, (Moraes et al., 1975; Mohan et al., 1978), C. congensis and $C$. salvatrix (Rodrigues et al., 2019). Resistance in Arabica coffees with introgression of $C$. canephora such as Icatu and Híbrido de Timor (HdT) derivatives also were found (Mohan et al., 1978; Petek et al., 2006; Ito et al., 2008).

To date, there are few available Arabica coffee cultivars with a high level of resistance to this disease. Many studies report that cultivars of Catuaí and Mundo Novo are susceptible (Mohan and Pavan, 1977; Mohan et al., 1978; Petek et al., 2006, Ito et al., 2008, Zocolli et al., 2011, Andreazi et al. al., 2015; Rodrigues et al., 2019). The cultivars of these two groups are the most cultivated in Brazil (Chalfoun and Reis, 2010). The cultivars Bourbon Amarelo (Mohan and Pavan, 1977), Acaiá Cerrado MG 1474, Topázio MG 1190 (Zocolli et al., 2011), IPR 98, IPR 99, IPR 100, IPR 107 (Ito et al. 2008), IAC 125 RN (Rodrigues et al., 2019) and Tupi IAC 1669-33 (Andreazi et al., 2015) were also identified as susceptible.

Field trial evaluations with natural occurrence of BHB in young plants 10 months after planting showed that IPR 102 presented $95 \%$ of plants with complete resistance, while IPR 103, IPR 104, IPR 108 and IAPAR 59 were partially resistant (Ito et al., 2008). However, it is necessary to confirm the resistance level of these cultivars developed by the Instituto de Desenvolvimento Rural do Paraná - IAPAR-EMATER (IDRParaná) in adult plants under field conditions.

The aim of this study was to assess the levels of resistance to BHB in Arabica coffee cultivars under field conditions and different spacings within the rows.

\section{Results and discussion}

\section{Resistance of the cultivars to bacterial-halo-blight}

Analysis of the BHB severity revealed a significant interaction between the plant spacing within the rows (SWR) and cultivars. Therefore, unfolding of SWR within each level of cultivars and cultivars within each level of SWR were performed.

Regarding the SWR separately, it was possible to observe that only IPR 102 presented a high level of resistance in all SWR. IPR 106 was more resistant than IPR 104 and IAPAR 59 at SWR $0.40 \mathrm{~m}$ and $0.50 \mathrm{~m}$. At $0.60 \mathrm{~m}$ SWR, IPR 106 did not differ from IAPAR 59 and IPR 103, whereas at $0.70 \mathrm{~m}$ this did not differ from IAPAR 59, IPR 103, IPR 104, IPR 107 and IPR 108 (Table 1). In all SWR, IPR 102 and IPR 106 were classified as highly resistant (HR) and moderately resistant (MR), respectively. IAPAR 59, IPR 103, IPR 104, IPR 107 and IPR 108 were classified as slightly resistant (SR) or MR, and considering the general mean grade, these four were classified as SR. The only cultivars that were of the most susceptible group in all SWR were Catuaí Vermelho IAC 99, Tupi IAC 1669-33, IPR 100 and IPR 101. These four cultivars, besides IPR 97, IPR 98, IPR 99 and IPR 105 were classified as susceptible (S) in at least two SWR (Table 1).

The high resistance level of IPR 102 observed in adult plants in our study. This corroborates with previous study by lto et al. (2008), in a field trial that was conducted on young plants (10 months after planting), in which IPR 102 was also considered resistant. Rodrigues et al. (2019) found that IPR 102 presented $100 \%$ of seedlings resistant to $\mathrm{BHB}$.

IPR 106 was MR, showing a mean severity grades higher than IPR 102, but it was lower than other cultivars, most of which did not differ from IAPAR 59 and IPR 103, considered intermediate resistance (Ito et al. 2008). In some cases, it was more resistant than these two. However, in the study by lto et al. (2008) it was verified that IPR 106 was susceptible. This difference was probably occurred due to age of our plants, which were older than the study by lto et al. (2008). Therefore, IPR 106 may have adult escape resistance under conditions of natural infections in the field, probably due to some morphological characteristics of the adult plant that provide less infection, multiplication and dissemination of the pathogen such as plant architecture, leaf size, rippling of leaf edges and higher plagiotropic ramification intensity. Some of these characteristics may promote a less favorable microclimatic condition for Pseudomonas syringae pv. garcae or fewer injuries to the leaves, which facilitate the penetration of this bacteria.

IAPAR 59, IPR 103, IPR 104 and IPR 108 showed intermediate resistance and, depending on SWR, were classified as MR or $\mathrm{SR}$, in the same way that was observed in young plants (Ito et al., 2008).

IPR 107 has been reported to be susceptible in young plants (Ito et al., 2008). However, in our study there was an indication that this cultivar may present a low level of resistance in adult plants. In all spacing within rows (SWR), this cultivar was classified as SR, which did not differ from IAPAR 59, IPR 103, IPR 104 and IPR 108.

In general, we observed that IPR 97, IPR 98, IPR 99, IPR 100, IPR 101, IPR 105, Catuaí Vermelho IAC 99 and Tupi IAC 1669-33 are susceptible, corroborating with other studies (Ito et al., 2008, Zocolli et al., 2011, Andreazi et al., 2015).

Intermediate resistance to $P$. syringae pv. garcae in cultivars derived from Híbrido de Timor (HdT) CIFC 832/2 as IAPAR 59, IPR 104 and IPR 107 was observed. It is probable that the resistance source of these cultivars is HdT CIFC 832/2. Partial resistance of $\mathrm{HdT}$ derivatives has been reported in previous studies (Mohan et al., 1978; Petek et al., 2006; Ito et al., 2008). However, it is also possible that the resistance of these three cultivars originated from the genitor Villa Sarchi. Rodrigues et al. (2019), reported $33.3 \%$ of resistant plants and $66.7 \%$ of susceptible plants to BHB.

IPR 102 and IPR 103 were originated from the same hybrid between 'Catuaí Vermelho IAC 99' and "Dwarf Icatu", named by the Instituto Agronômico (IAC) as H9878, generating several $F_{1}$ plants. The "Dwarf Icatu" was used to obtain these two cultivars but does not have backcrossing with Mundo Novo. Therefore, it is very different from the commercial varieties 
Table 1. Mean grades of bacterial-halo-blight (BHB) severity and resistance levels ( $R L$ ) in Arabica coffee cultivars, assessed in December 2016, in a field trial performed in Londrina (Paraná state, Brazil), with different spacings within the rows.

\begin{tabular}{|c|c|c|c|c|c|c|c|c|c|c|}
\hline \multirow[t]{3}{*}{ Cultivars $^{(1)}$} & \multicolumn{8}{|c|}{ Spacing within the rows } & \multicolumn{2}{|c|}{ General means } \\
\hline & \multicolumn{2}{|c|}{$40 \mathrm{~cm}$} & \multicolumn{2}{|c|}{$50 \mathrm{~cm}$} & \multicolumn{2}{|c|}{$60 \mathrm{~cm}$} & \multicolumn{2}{|c|}{$70 \mathrm{~cm}$} & & \\
\hline & $\mathrm{BHB}^{(2)}$ & $\mathrm{RL}^{(3)}$ & $\mathrm{BHB}^{(2)}$ & $\mathrm{RL}^{(3)}$ & $\mathrm{BHB}^{(2)}$ & $\mathrm{RL}^{(3)}$ & $\mathrm{BHB}^{(2)}$ & $\mathrm{RL}^{(3)}$ & $\mathrm{BHB}^{(2)}$ & $\mathrm{RL}^{(3)}$ \\
\hline Tupi & 4.37 a $\mathrm{A}$ & $S$ & 4.67 a $A$ & $S$ & 4.72 a $A$ & $S$ & 4.53 a $A$ & $S$ & 4.57 & $\mathrm{~S}$ \\
\hline Catuaí & 4.72 a $A$ & $\mathrm{~S}$ & 4.93 a $\mathrm{A}$ & $S$ & 3.95 a $A$ & SR & 4.22 a $A$ & $S$ & 4.46 & $\mathrm{~S}$ \\
\hline IPR 100 & 4.87 a $\mathrm{A}$ & $S$ & 4.33 a $\mathrm{A}$ & $S$ & 4.33 a $\mathrm{A}$ & $\mathrm{S}$ & 4.20 a $A$ & $S$ & 4.43 & $\mathrm{~S}$ \\
\hline IPR 101 & 4.67 a $A$ & $S$ & 4.65 a A & $S$ & 4.33 a $\mathrm{A}$ & $S$ & 3.93 a $A$ & SR & 4.40 & $\mathrm{~S}$ \\
\hline IPR 105 & 4.33 a $\mathrm{A}$ & $S$ & 4.33 a A & $S$ & $3.87 \mathrm{~b} \mathrm{~A}$ & SR & 3.80 a $A$ & SR & 4.08 & $\mathrm{~S}$ \\
\hline IPR 98 & 4.58 a $\mathrm{A}$ & $S$ & 4.43 a A & $S$ & $3.47 \mathrm{~b} \mathrm{~B}$ & SR & 3.80 a B & SR & 4.07 & $S$ \\
\hline IPR 99 & $3.78 \mathrm{~b} \mathrm{~B}$ & SR & 4.47 a A & $S$ & $3.37 \mathrm{~b} \mathrm{~B}$ & SR & 4.38 a $A$ & $S$ & 4.00 & $S$ \\
\hline IPR 97 & 4.40 a A & $S$ & $4.02 \mathrm{~b} \mathrm{~A}$ & $S$ & $3.58 \mathrm{~b} \mathrm{~A}$ & SR & 3.73 a A & SR & 3.93 & SR \\
\hline IPR 108 & $3.62 \mathrm{~b} \mathrm{~A}$ & $S R$ & $3.98 \mathrm{~b} \mathrm{~A}$ & SR & $3.32 \mathrm{~b} \mathrm{~B}$ & SR & 2.87 b B & MR & 3.45 & $S R$ \\
\hline IPR 107 & $3.78 \mathrm{~b} \mathrm{~A}$ & $S R$ & $3.47 \mathrm{~b} \mathrm{~A}$ & SR & $3.25 \mathrm{~b} \mathrm{~A}$ & SR & $3.13 \mathrm{~b} \mathrm{~A}$ & SR & 3.41 & $S R$ \\
\hline IPR 104 & $2.97 \mathrm{cA}$ & MR & $3.00 \mathrm{c} \mathrm{A}$ & SR & $3.60 \mathrm{~b} \mathrm{~A}$ & SR & $3.33 \mathrm{~b} \mathrm{~A}$ & SR & 3.23 & SR \\
\hline IPR 103 & $3.60 \mathrm{~b} \mathrm{~A}$ & $S R$ & $3.50 \mathrm{~b} \mathrm{~A}$ & SR & 2.62 c B & $\mathrm{MR}$ & $3.00 \mathrm{~b} \mathrm{~B}$ & $S R$ & 3.18 & $S R$ \\
\hline IAPAR 59 & $3.10 \mathrm{c} \mathrm{A}$ & SR & $3.12 \mathrm{cA}$ & SR & $2.62 \mathrm{cA}$ & $\mathrm{MR}$ & $3.17 \mathrm{~b} \mathrm{~A}$ & SR & 3.00 & $S R$ \\
\hline IPR 106 & $2.27 \mathrm{~d} \mathrm{~A}$ & $\mathrm{MR}$ & $2.33 \mathrm{~d} \mathrm{~A}$ & MR & $2.27 \mathrm{cA}$ & $\mathrm{MR}$ & $2.47 \mathrm{~b} \mathrm{~A}$ & $\mathrm{MR}$ & 2.33 & $\mathrm{MR}$ \\
\hline IPR 102 & 1.27 e $A$ & HR & 1.39 e $A$ & $\mathrm{HR}$ & $1.33 \mathrm{~d} \mathrm{~A}$ & HR & $1.00 \mathrm{cA}$ & HR & 1.25 & $\mathrm{HR}$ \\
\hline $\begin{array}{l}\text { General } \\
\text { means }\end{array}$ & 3.75 & & 3.77 & & 3.38 & & 3.44 & & 3.59 & \\
\hline$C V=4.18 \%$ & & & & & & & & & & \\
\hline
\end{tabular}

(1) Cultivars ordered decreasingly based on the general mean grade of BHB. ${ }^{(2)}$ Means followed by the same lowercase letter in the column and upper case in the row did not differ by Scott-Knott mean clustering test at $5 \%$ significance. ${ }^{(3)}$ Resistance levels of the cultivars, based on mean grades of BHB severity, where: 1.00 to $1.49=$ highly resistant $(\mathrm{HR}) ; 1.50$ to $1.99=$ resistant $(\mathrm{R}) ; 2.00$ to $2.99=$ moderately resistant (MR); 3.00 to 3.99 = slightly resistant (SR); 4.00 to $5.00=$ susceptible $(\mathrm{S})$.

Table 2. Arabica coffee cultivars assessed for resistance to BHB in a field trial performed in Londrina, Paraná state, Brazil.

\begin{tabular}{|c|c|}
\hline Cultivar & Origin $^{(2)}$ \\
\hline IPR 97 & "Villa Sarchi CIFC 971/10" x “HdT CIFC 832/2" \\
\hline IPR 98 & "Villa Sarchi CIFC 971/10" x “HdT CIFC 832/2" \\
\hline IPR 99 & "Villa Sarchi CIFC 971/10" x “HdT CIFC 832/2" \\
\hline IPR 100 & 'Catuaí V. IAC 81' x ('Catuaí V. IAC 81' x IAC 1110-8) \\
\hline IPR 101 & 'Catuaí V. IAC 81' x ('Catuaí V. IAC 81' x IAC 1110-8) \\
\hline IPR 102 & ‘Catuaí V. IAC 99’ x “Dwarf Icatu” \\
\hline IPR 103 & “Catuaí V. IAC 99’ x “Dwarf Icatu” \\
\hline IPR 104 & "Villa Sarchi CIFC 971/10" x “HdT CIFC 832/2" \\
\hline IPR 105 & 'Catuaí V. IAC 81' x ('Catuaí V. IAC 81' x IAC 1110-8) \\
\hline IPR 106 & "Icatu IAC 925" x Unknown dwarf Arabica coffee \\
\hline IPR 107 & 'IAPAR 59’ x 'Mundo Novo IAC 376-4’ \\
\hline IPR 108 & 'IAPAR 59’ x ('Catuaí V. IAC 99’ x “Dwarf Icatu”) \\
\hline IAPAR 59 & "Villa Sarchi CIFC 971/10" x “HdT CIFC 832/2" \\
\hline Catuaí V. IAC $99^{(1)}$ & 'Caturra Amarelo' x “Mundo Novo” \\
\hline Tupi IAC 1669-33 & "Villa Sarchi CIFC 971/10" x “HdT CIFC 832/2" \\
\hline
\end{tabular}

derived from Icatu, such as Icatu Vermelho IAC 4045, Icatu Amarelo IAC 2944 and Icatu Precoce IAC 3282. The "Dwarf Icatu" was originated from the crossing between "Coffea canephora with duplicate number of chromosomes" and "dihaploid Bourbon Vermelho with duplicate number of chromosomes", which was crossed with a line of Catuaí Amarelo (Sera et al., 2017). As there is less backcrossing with Mundo Novo, IPR 102 and IPR 103 have greater chance to present higher levels of resistance to $\mathrm{BHB}$, originating from $C$. canephora, than the Icatu commercial varieties. IPR 108 was also originated from 'Catuaí Vermelho IAC 99' x "Dwarf Icatu", but it was backcrossed with IAPAR 59. Thus, the resistance of
IPR 108 may have originated from both the "Dwarf Icatu" and the 'IAPAR 59'.

IPR 106 was MR and it is derived from the spontaneous crossing between Icatu 925 (H4782-7-925) and an unknown dwarf Arabica coffee. Mohan et al. (1978) observed moderate resistance in Icatu $\mathrm{H} 4782-7$, which later raised to Icatu IAC 925. Then the resistance of IPR 106 probably originated from Icatu IAC 925 or as previously reported, may be an adult plant resistance of the escape type.

IPR 102 ('Catuaí V. IAC 99' x "Dwarf Icatu”) showed a high level of resistance and probably should be a resistance inherited from "Dwarf Icatu" because Catuaí is susceptible. The different levels of intermediate resistance of cultivars IPR 103, IAPAR 59, 
IPR 108, IPR 104 and IPR 107 are probably quantitative resistance. In IPR 106, there may be that same quantitative resistance combined with an escape resistance. Fernandes et al. (2020) found that IPR 102 and IPR 106 have resistance to wounds caused to the leaf, so both can have an escape-type resistance.

Other HdT-derivatives cultivars such as IPR 97, IPR 98, IPR 99 and Tupi IAC 1669-33, and those derived from 'Catuaí V. IAC 81 'x ('Catuaí V. IAC 81' x IAC 1110-8) as IPR 100, IPR 101 and IPR 105 were susceptible.

\section{Effect of planting density on bacterial-halo-blight severity}

Regarding the general mean grade, higher BHB intensities occurred at the denser SWR (e.g. $0.40 \mathrm{~m}$ and $0.50 \mathrm{~m}$ ) (Table 1). In these SWRs, a more favorable microclimate could have occurred for the infection, multiplication and dissemination of $P$. syringae pv. garcae or may have favored a greater amount of leaf wounds due to the friction between them, while they are closer in more SWR. In a field trial with adult plants from 18 Arabica coffee cultivars and simultaneous natural occurrence of BHB and BLS, it was observed that the increase in leaf wounds, caused an increase in the severity of these two diseases (Fernandes et al., 2020). Higher BHB intensities at the SWR $0.40 \mathrm{~m}$ and $0.50 \mathrm{~m}$ were occurred in IPR 103 and IPR 108, both with intermediate resistance, in which a greater inoculum pressure or amount of leaf wounds could have occurred, causing them to behave as more susceptible. The same was occurred in IPR 98, but for IPR 99 the BHB intensity was higher in SWR $0.50 \mathrm{~m}$ and $0.70 \mathrm{~m}$.

More susceptible cultivars such as Catuaí, Tupi, IPR 100, IPR 101, IPR 105 and IPR 97 did not differ at the different SWR. For the cultivars IAPAR 59, IPR 102, IPR 104, IPR 106 and IPR 107, also there was no differences were observed in the $B H B$ intensity between the SWR, indicating a higher resistance stability. In general, although these cultivars did not differ statistically, the BHB mean grades were higher at denser SWR.

\section{Materials and methods}

\section{Field trial}

The field trial was installed in December 2013 at the IDRParaná experimental station (lat 2321'45" S, long 5109'48" W, alt $585 \mathrm{~m}$ asl), in Londrina, Paraná state, Brazil. The climate is classified as Cfa, according to Köppen. The average annual temperature in Londrina is $21.1^{\circ} \mathrm{C}$ and the annual average precipitation varies from 1400 to $1600 \mathrm{~mm}$ per year. The experiment was planting at the $2.50 \mathrm{~m}$ spacing inter-row, using randomized blocks design, in a $4 \times 15$ factorial scheme, with three replications and five plants per plot. The factors consisted of four SWR $(0.40 \mathrm{~m}, 0.50 \mathrm{~m}, 0.60 \mathrm{~m}$ and $0.70 \mathrm{~m})$ and 15 cultivars. Soil fertilization and corrections, besides agricultural practices, were made according to the recommendation for coffee crop (Matiello et al., 2016). In the year 2016, antibiotics, resistance inducers and copper-based products were not applied, which could reduce the BHB intensity.

\section{Plant materials}

The 15 Arabica coffee cultivars developed by IDR-Paraná and IAC genetic breeding programs were assessed to BHB. They have different origins (Table 2). As a susceptible check, the cultivar Catuaí Vermelho IAC 81 was used (Ito et al., 2008).

\section{Resistance assessment}

In natural infection condition, an assessment of the BHB severity was made in December 2016 (36 months after planting seedlings with six pair of leaves), based on the symptoms described by Amaral et al. (1956). Severity was evaluated using a grade scale, ranging from 1 to 5 (Sera et al., 2017), in which: $1=$ no necrotic lesions; $2=0.01$ to $3 \%$ of the leaves with small necrotic lesions, with yellowish halo (up to $0.5 \mathrm{~cm}$ ); $3=3.01$ to $15 \%$ of the leaves with small and medium lesions (up to $1 \mathrm{~cm}$ ), with possible presence of $1 \%$ large lesions (greater than $1 \mathrm{~cm}$ ); $4=15.01$ to $30 \%$ of the leaves with small to large lesions; $5=$ more than $30 \%$ of the leaves with small to large lesions, with possible die-back of the branches. Disease severity was evaluated in the whole plant, from the upper third to the lower third of the plant canopy. However, only unexpanded young leaves to sixth pair of fully expanded leaves were considered. This was done because the leaves located further inside the plant had low disease severity or no lesions. The resistance levels of the cultivars were based on the mean BHB severity grades, where: 1.00 to $1.49=$ highly resistant $(\mathrm{HR}) ; 1.50$ to $1.99=$ resistant $(\mathrm{R}) ; 2.00$ to $2.99=$ moderately resistant $(\mathrm{MR}) ; 3.00$ to 3.99 = slightly resistant $(\mathrm{SR}) ; 4.00$ to $5.00=$ susceptible $(\mathrm{S})$.

\section{Identification of Pseudomonas syringae pv. garcae}

A sample composed of 30 leaves of this experiment was sent to the Biological Institute, Campinas-SP, Brazil to pathogen identify.

The obtained isolates were submitted to the LOPAT tests (levan, oxidase, protopectinase in potato disks, arginine dihydrolase, and tobacco HR) and fluorescent pigment in BK medium (King et al., 1956). All strains presented the results, + - - + to the respective tests and variable response to fluorescent pigment, indicating the inclusion of the obtained isolates in Group I of $P$. syringae.

Subsequently, the strains were subjected to biochemical (Lelliot et al, 1966; Young and Triggs, 1994; Schaad, 2001; Rodrigues et al, 2017) and pathogenicity tests. The results determined the occurrence of $P$. syringae pv. garcae, in the experimental field.

\section{Statistical analysis}

BHB severity data were transformed to $\sqrt{x+1}$ at level of mean of plots. ANOVA, Bartlett test of homogeneity of variances, Shapiro-Wilk normality test and Scott-Knott mean clustering test at $5 \%$ significance were performed using the $\mathrm{R}$ software version 3.3.0 (R Core Team 2016), package ExpDes (Ferreira et al., 2013).

\section{Conclusion}

In denser plantings, the BHB severity was higher, and some cultivars behaved more susceptible in these spacings. IPR 102 had a high level of resistance to BHB in adult plants, at all spacings within the rows. IPR 106 showed moderate resistance at all spacings within the rows and can have adult plant resistance of escape type, under natural field conditions. IAPAR 
59, IPR 103, IPR 104, IPR 107 and IPR 108 showed a lower level of resistance than the cultivars IPR 102 and IPR 106. Some HdT-derived cultivars such as IPR 97, IPR 98, IPR 99 and Tupi IAC 1669-33, besides cultivars IPR 100, IPR 101 and IPR 105, derived from IAC 1110-8, were susceptible.

\section{Acknowledgments}

We thank Conselho Nacional de Desenvolvimento Científico e Tecnológico (CNPq) for the scholarship granted and Consórcio Pesquisa Café for the financial support to this research.

\section{References}

Amaral JF, Teixeira GC, Pinheiro ED (1956) A bactéria causadora da "Mancha Aureolada" do cafeeiro. Arqu do Instituto Biológico. 23:151-155.

Andreazi E, Sera GH, Faria RT, Sera T, Shigueoka LH, Carvalho FG, Carducci FC, Chamlet D (2015) Desempenho de híbridos F1 de café arábica com resistência simultânea a ferrugem, mancha aureolada e bicho mineiro. Coffee Sci. 10:375-382.

Chalfoun SM, Reis PR (2010) História da cafeicultura no Brasil. In: Reis PR, Cunha RL da (eds) Café arábica: do plantio à colheita. EPAMIG SM, Lavras, p. 23-85.

Fernandes LE, Santos WG dos, Carducci FC, Fonseca IC de B, Rodrigues LMR, Beriam LOS, Pereira CTM, Shigueoka LH, Sera GH (2020) Resistance of Arabica coffee cultivars to leaf wounds and Pseudomonas syringae under field conditions. Austr J Crop Sci. 14:46-50.

Ferreira EB, Cavalcanti PP, Nogueira DA (2013) ExpDes: experimental designs package. $\mathrm{R}$ package version 1.1.2.

Ithiru JM, Gichuru EK, Gitonga PN, Cheserek JJ, Gichimu BM (2013) Methods for early evaluation for resistance to bacterial blight of coffee. African J of Agric Res. 8:2450-2454.

Ito DS, Sera T, Sera GH, Del Grossi L, Kanayama FS (2008) Resistance to bacterial blight in arabica coffee cultivars. Crop Breeding and Appl Biotechnol. 8:99-103.

King EO, Ward MK, Raney DE (1956) Two simple media for the demonstration of pycoyanin and fluorescein. J Lab Clin Med. 4:301-307.

Korobko A, Wondimagegne E (1997) Bacterial blight of coffee (Pseudomonas syringae pv. garcae) in Ethiopia. In: Rudoldh K, Burr TJ, Mansfield JW, Stead D, Vivian A, Von Kietzele J. Pseudomonas syringae and related patogens. Netherlands Springer. p. 538-541.

Lelliott RA, Billing E, Hayward AC (1966) A determinative scheme for the fluorescent plant pathogenic pseudomonads. J of Appl Microbiol. 29:470-489.

Matiello JB, Santinato R, Almeida SR, Garcia AWR (2016) Cultura de café no Brasil: Manual de recomendações. ed. 2015. Futurama Editora, Varginha, MG.
Mohan SK, Cardoso RL, Pavan MA (1978) Resistência em germoplasma de Coffea ao crestamento bacteriano incitado por Pseudomonas garcae Amaral et al. Pesq Agrop Brasileira. 13:53-64.

Mohan SK, Pavan MA (1977) Resistência em cultivares e espécies de Coffea à Pseudomonas garcae Amaral et al. Fitopatol Brasileira. 2:91.

Moraes SA, Sugimori MH, Tomazello-Filho M, Carvalho P de CT de (1975) Resistência de cafeeiros a Pseudomonas garcae. Summa Phytopathol. 1:105-110.

Patrício FRA, Almeida IMG, Barros BC, Santos AS, Frare PM (2008) Effectiveness of acibenzolar-S-methyl, fungicides and antibiotics for the control of brown eye spot, bacterial blight, brown leaf spot and coffee rust in coffee. Ann Appl Biol. 152:29-39.

Patrício FRA, Beriam LOS, Rossi A, Moraes A, Almeida IMG (2010) Controle químico da mancha aureolada em uma região montanhosa. Trop. Plant Pathol. 35:S119.

Petek MR, Sera T, Sera GH, Fonseca IC de B, Ito DS (2006) Seleção de progênies de Coffea arabica com resistência simultânea à mancha aureolada e à ferrugem alaranjada. Bragantia. 65:65-73.

$R$ Core Team (2016) R: A language and environment for statistical computing. R Foundation for Statistical Comput Vienna.

Ramos AH, Shavdia LD (1976) A dieback of coffee in Kenya. Plant Dis Rep Washington. 60:831-835.

Rodrigues LMR, Destéfano, SAL, Almeida IMG de, Beriam LOS, Braghini, MT, Guerreiro-Filho O (2019) Multiple resistance to bacterial halo blight and bacterial leaf spot in Coffea spp. Arq do Instituto Biológico. 86:1-9.

Rodrigues LMR, Sera GH, Guerreiro Filho O, Beriam LOS, Almeida IMG de (2017) First report of mixed infection by Pseudomonas syringae pathovars garcae and tabaci on coffee plantations. Bragantia. 76:543-549.

Schaad NW, Jones JB, Chun W (2001) Laboratory guide for the identification of plant pathogenic bacteria (ed. 3). Am Phytopathol Soc (APS Press). p 373.

Sera GH, Sera T, Fazuoli LC (2017) IPR 102 - Dwarf Arabica coffee cultivar with resistance to bacterial halo blight. Crop Breeding and Appl Biotechnol. 17:403-407.

Xuehui B, Lihong Z, Yongliang H, Guanghai J, Jinhong L, Zhang $H$. (2013) Isolation and identification of the pathogen of coffee bacterial blight disease. Chin J Trop Crop. 34:738-742.

Young, JM, Triggs CM. (1994) Evaluation of determinative tests for pathovars of Pseudomonas syringae van Hall 1902.J of Appl Microbiol. 77:195-207.

Zoccoli DM, Takatsu A, Uesugi CH (2011) Ocorrência de mancha aureolada em cafeeiros na Região do Triângulo Mineiro e Alto Paranaíba. Bragantia. 70:843-849. 